\title{
WALT WHITMAN'S “LIVELY CORPSE” IN 1871: THE AMERICAN PRESS ON THE RUMOR OF WHITMAN'S DEATH
}

\section{TODD RICHARDSON}

ACCORDING TO A TELEGRAPHIC DISPATCH released on March 25, 1871, "Walter Whitman was killed" by a railroad train near Croton, New York. In the fiercely competitive publishing world of New York City, many newspaper editors must have been tempted to be the first to break the news that the poet Walt Whitman was dead. Most papers, however, played it safe and only reprinted the dispatch. But the New York World made a disastrous assumption and transformed the dispatch into a long obituary for the famous Walt Whitman. ${ }^{1}$ Since the World was trusted by editors across the country, other papers, such as the Philadelphia Bulletin and the Louisville Courier-fournal, reprinted all or part of the obituary notice, and, as far as I can tell, did not print retractions. Undoubtedly the rumor persisted. In a letter of June 29, 1871, to Ellen O'Connor, Whitman himself commented that "my death by railroad smash permeated the lower orders, (I suppose at second $\&$ third hand) $\&$ the rectification in many cases never reached them. So I hardly stir out in New York."2

Editors, having only telegraphic reports and unreliable "second \& third hand" information to rely on, commonly reported gossip which they hoped to be news. Mistaken obituary reports were particularly common. ${ }^{3}$ Of course, journalists started the infamous rumor that Mark Twain had nearly died on one of his trips to Europe. The great writer quipped that "reports of my death have been grossly exaggerated."

Scholars have been aware that in 1871 some American newspapers made the false report that Whitman had been killed in a railroad accident. Whitman referred to the rumor in his letters of June 29, 1871, and January 27, 1873, and Willard E. Martin reprinted a short report from the March 28, 1871, Boston fournal in the Walt Whitman Review in 1977. ${ }^{5}$ But Whitman scholars have not been aware of the breadth and significance of the newspaper coverage, as I found after Steven OlsenSmith alerted me to a report he had found in the New York World (April 1, 1871). Here I reprint some four dozen new reports I have located.

Even though many of the newspaper accounts consist of brief notices of the rumor and brief denials, the episode, like any media sensation, flushed out a considerable amount of contemporary commentary 
that otherwise would have remained unvoiced. Many articles must still be unlocated, since at least four papers, the Philadelphia Press, the Cincinnati Daily Gazette, the Chicago Tribune, and the St. Louis Missouri Democrat, all reported on March 28 that "the press for the country . . . is teeming with sketches of himself [Whitman] and books." Reports from Washington, Brooklyn, and New York tended to show greatest familiarity with Whitman the man and the writer, but surprisingly wellinformed reports also surfaced in Chicago, New Orleans, and Louisville. Several reporters had at their fingertips a range of wonderfully apt quotations from Leaves of Grass-quotations which demonstrate just how rapidly Whitman's poetry had been assimilated into the reading culture. The articles also clinched what American journalists saw as Whitman's international reputation. Comparisons to Swinburne had already been made in the press, but now in newspaper headlines Whitman was repeatedly called "The American Swinburne." Further, during the time of the rumor, the press in many cities grudgingly acknowledged Swinburne's own high opinion of Whitman. Some of the articles refer to publications on Whitman that are not in Scott Giantvalley's Walt Whitman, 1838-1939: A Reference Guide, ${ }^{6}$ and others put on record previously unknown comments by people who knew Whitman.

Scholars will be challenged to determine what is new in the more substantial of these reports, particularly the piece by "Miss Grundy" (the Washington correspondent for the New York World) in the April 1, 1871, World, which is an interview with Whitman at his "Nook in the Attorney-General's Office." Enjoying the spectacular view, which included the Fairfax Seminary where he had nursed soldiers, Whitman reflected to this reporter that his experience of the Civil War was the most "fertile" portion of his life, since he witnessed the "integrity and energy of the people, as displayed in a trying emergency." The interview also gave Whitman an opportunity to demonstrate just how alive he was and to correct other misinformation in the World obituary of March 27, 1871.

In looking for notices, I concentrated primarily on east coast cities, particularly New York, where the rumor started, and Washington, where Whitman was living at the time. I have looked at all the Washington, Baltimore, and Brooklyn newspapers I could find. I looked through a dozen New York City newspapers and several from Boston. Discovering that news of the rumor had spread to the Midwest, I checked the papers of that region, and from other cities as far away as San Francisco, with some surprising results, such as a lengthy article in the New Orleans Picayune, which asserted, with overt sectional animus, that Whitman was not remembered in journalistic circles there. Others may supplement my research with good success, for there is simply no way of knowing the length and the nature of what will be put in print during any media sensation. 
My intent here is to print the known articles in chronological order. When different cities print articles on the same day, I arrange them in geographical sequence, east to west. For papers within cities on the same day, I divide by morning and evening, and within those categories by alphabetical order. ${ }^{7}$

March 25, 1871, New York Evening Post

\section{Killed by a Railroad Train}

[Despatch to the Associated Press]

Croton, March 25. Walter Whitman was killed on the railroad this morning by the New York Express train, bound north.

March 26, 1871, New York Herald

\section{Killed by a Railroad Train}

Croton, N.Y., March 25, 1871.

Walter Whitman was killed on the railroad this morning by the New York express train bound north.

March 26, 1871, New York Times

WALTER WHITMAN was killed yesterday on the Hudson River Railroad, near Croton, N.Y.

March 26, 1871, New York World

Walter Whitman was killed on the railroad at Croton, N.Y., yesterday morning, by the New York express train bound north.

March 27, 1871, New York Sun, morning edition

Walter Whitman was killed on the railroad at Croton, N.Y., on Saturday.

March 27, 1871, New York Tribune, morning edition

Walter Whitman was killed at Croton, N.Y., on Saturday, by the New York express train, bound north.

March 27, 1871, New York World, morning edition

OBITUARY.

Walt Whitman.

Our telegrams yesterday morning announced the death of Walter Whitman, crushed to death by a railroad train at Croton, N.Y. We presume that 
this is the famous Walt Whitman whose name and works have become household works [words] amongst us. In a scene of busy life on a high road of commerce such as he loved to frequent the most American bard of America has met his fate. His end came early to this strong man, so full of life and scarcely more than half a century old, yet little cared he of its anticipation or delay, for he held death and life of equal account if his now quaint verses have not belied him-

Has any one supposed it lucky to be born?

I hasten to inform him or her it is just as lucky to die, and I know it.

Walt Whitman "the inspired bard and prophet of his era and land," the American Dante, Aeschylus, or Shakespeare, as his enthusiastic admirer, Mr. O'Connor, would have him called, was in his fifty-second year at the time of his sudden death. He was a native of this State, having been born in 1819 at Westhills, of American parents. His father was of English and his mother of Dutch stock, as he has sung himself-

My tongue, every atom of my blood formed

From this soil, this air,

Born here of parents born here, from parents

The same, and their parents the same.

His earlier life was not surrounded by any of the advantages conferred by ancestral position or wealth, and his education was limited to that which he could receive in the village common school, or gather by his own exertions. Books were the least important sources of his knowledge. From his earliest years he reveled in the study of nature and humanity, in the open field and on the "populous pavement," of that Manahatta which he has so affectionately celebrated. Nevertheless, though his study was chiefly of himself and of his fellows, he gathered together in his wayward career a rare stock of curious lore which often mingles itself, with the voices of nature speaking through him. Had fate permitted it, his quiet, easy nature would have kept him forever a worshiper of nature, a silent spectator and admirer rather than active participator in the work of life; his tastes would have made him what he often described-a sublime loafer, enjoying the glorious present and indifferent about the future; but even Walt Whitmans, able to "enjoy themselves on bread and water" as he was, must do some work to win that which can only be obtained "in the sweat of the brow." He began life as a school-teacher; he passed from that to the compositor's case in a printing office, and has toiled many days as a carpenter erecting frame houses. He has travelled [sic] widely through the country. He has camped on the prairie, driven stages on Broadway, piloted ferry boats on the East River, and once in New Orleans edited a journal, but New York was his favorite abode.

Manhattan streets with their powerful throbs, with the beating drums, as now

The endless, noisy chorus, the rustle and clank of muskets (even the sight of the wounded),

Manhattan crowds with their turbulent musical chorus-with varied chorus and light 
of the sparkling eye.

Manhattan faces and eyes forever for me.

...

O superb! O Manhattan! My own, my peerless.

$\mathrm{O}$, strongest, you in the hour of danger, in crisis.

$\mathrm{O}$, truer than steel.

What Walt Whitman had not seen of the lower strata of New York society was not worth studying, and his recollections of it strongly impregnate his poetry. The life that he saw from the pilot box of the ferry-boat, and from the driver's seat of the Broadway omnibus, gleams again in the picturesque thoughts which strikes the mental vision from his "Leaves of Grass" and "Drum Taps." For years his quiet, harmless life was past [sic] in obscurity, making few friends and no enemies. Probably Walt Whitman has left no enemy behind him-he, at least, was unconscious of ill-will towards any one. Every one who met him was magnetized by his irrepressible and magnificent good nature; and among the children of nature of our lower ten he was at one time fairly worshiped, if we can believe one of his admirers of another order who once undertook to investigate the subject. "Who's that?" answered a deck hand of a Brooklyn ferry-boat once to an Anglo-American litterateur. "Why, that's Walt Whitman. Every one knows Walt Whitman." The interviewer pushing the questions further, asked did he know that Walt was a poet, and had written a book. "Why no," was the answer, "I never hearn it, but Walt is a fust rate fellow." That was his character among men who knew him simply for himself and through himself.

In this obscurity he had lived for years, sometimes feeling that there was a fire burning within him, which he could not or did not care to extinguish, but which burned with too weak an energy to force more than a feeble utterance. What he did write was too frequently laughed at by his friends, and few did more than say that some of the thoughts were striking, although crude, but that their form was simply abominable. To the present day, although his works have passed through numberless editions, both here and abroad, the popular criticism of them is frequently of this class. But a great occasion having fanned the smouldering elements within him into the poetic flame he began his task.

In the year 80 of the States,

I, now 36 years years [sic] old, in perfect health begin,

Hoping to cease not until death.

It is difficult to describe the enthusiasm sometimes united with horror, with which his earlier publications were received. With difficulty he found a publisher, and the editions bore the names of no publishers; some of the earlier were set up by Whitman himself. Men like Emerson recognized in them immense power, and Whitman, who was always a devoted admirer of Emerson, received from that philosopher the highest commendation for his work. "At first I rubbed my eyes," says Mr. Emerson, "to find if this new sunbeam might not be an illusion. I greet you at the beginning of a great career, which yet must have had a long foreground somewhere for such a start." Walt, dreamer as he 
was, did a good stroke of business by publishing this letter in subsequent editions, and Emerson's unfortunate endorsement brought "Leaves of Grass" into places where it otherwise never should have reached. The polished lechery of Swinburne was comparatively chaste in contrast with some of Whitman's passages. Emerson subsequently revised his opinion of this "new sunbeam," and probably feels now that no author can safely be approved sooner than he can be declared happy. Thoreau, who was an ardent admirer of Whitman, says of some of these warm passages: "There are two or three places in the book which are disagreeable, simply sensual. It is as if the beast spoke. Of course, Whitman can communicate to us no experience, and if we are shocked, whose experience is it that we are reminded of?" Mr. Whitman has found others equally ready to defend his openness of speech, while not a few have seen nothing in it to admire. The late Mr. Lincoln having read his "Leaves of Grass," so far interested himself in him as to procure his appointment in the Department of the Interior. The attention of Mr. Harlan, of Iowa, the Secretary of the Interior, having been called to some passages of this volume, that pious gentleman removed him. Great excitement followed, and Mr. W. D. O'Connor having published "The Good Grey Poet, a Vindication," basing his explanation on the plainness of speech used in many volumes of venerable repute, Walt Whitman was restored to place in the Attorney-General's office. The war had made deep impression on Whitman, and to some of these he has given eloquent but peculiar expressions in his "Drum Taps[.]" While residing in Washington during the war he was of immense service in the hospitals. $\mathrm{He}$ was eminently suited by nature for the duties of nurse, and the same magnetic qualities which had won him hosts of friends on the ferry boats and 'longshore in New York; on the levees of New Orleans, and on the prairies of the Western country, drew to him all the sick with whom he had to deal.

So magnificent a physique few men ever possessed. His strong, well-knit form was perfectly superb. Mr. Moncure D. Conway, who interviewed him shortly after he became famous, describes him as he appeared when bathing off Staten Island as suggesting a picture of Bacchus which hung up in the poet's humble study. That study was a curious nook; it contained no books except a Bible and Homer, and but two pictures, line engravings-Silenus and Bacchus. But it permitted his free egress to the sandy shore, where, in full view of the surf striking on the beach, and with the blazing sun striking down on him, he found it cool at 100 degrees Fahrenheit. Here he thought out these turbulent thoughts which balanced the reader between a smile and admiration. For nothing had Whitman a grander contempt than for the modern poets of today. He wrote strongly against the irrational imitation in American literature of everything European, "instead of mighty and vital breezes, proportionate to our continent, with its powerful races of men its tremendous historic events, its great oceans, its mountains, and its illimitable prairies, I find a few silly little fans, languidly moved by shrunken fingers." Perhaps he had the ambition to found a new school of poetry. What its leading idea would be he has explained: "To give something to our literature which will be our own, with neither foreign spirit nor imagery nor form, but adapted to our case, grown out of our associations, boldly portraying the West, strengthening and intensifying the national love, and finding the entire fountain of its birth and growth in our country." 
Whitman was not very successful as a prose writer. He contributed a turgid article to the Galaxy, some years ago, which was most remarkable for its ambitious English. His poetical works have been republished in England, W. M. Rossetti editing one edition of them. Lord Strangford has reviewed them in the Pall Mall Gazette, Robert Buchanan has written on them for the Broadway, and the Fortnightly Review, the Saturday Review, the North American Review, and various other journals of criticism have noticed this peculiar phenomenon of American literature. What his worth in letters can hardly be discussed here, but to the average reader he will seem rather a curiosity than a poet, and his works will suggest the contortions rather than the inspiration of the sybil. He is popularly regarded as the American Swinburne, but it is difficult to trace in him any of the grace or elegance of that poet.

The following passage, taken almost at random from his "Song of the Broad-axe," is not the worst he has written:

\section{What says Walt Whitman?}

I see the European headsman;

He stands mask'd, clothed in red, with huge legs and strong naked arms,

And leans upon a ponderous axe.

Whom have you slaughtered lately, European headsman?

Whose is that blood upon you so wet and sticky?

I see the clear sunsets of the martyrs,

I see from the scaffolds the descending ghosts,

Ghosts of dead lords, uncrowned ladies, impeached ministers, rejected kings,

Rivals, traitors, disgraced chieftains, and the rest,

I see those who in any have died for the just cause;

The seed is spare, nevertheless the crop shall never run out;

(Mind you, $\mathrm{O}$ foreign kings, the crop shall never run out.)

America! I do not vaunt my love for you;

I have what I have.

The axe leaps!

The solid forest gives fluid utterances;

They tumble forth, they rise and form,

Hut, tent, landing, survey,

Flail, plough, pick, crowbar, spade,

Shingle, rail, prop, wainscot, jamb, lath, panel, gable,

Citadel, ceiling, saloon, academy, organ, exhibition house, library,

Cornice, trellis, pilaster, balcony, window, shutter, turret, porch,

Hoe, rake, pitchfork, pencil, wagon, staff, saw, jackplane mallet, wedge, rounce,

Chair, tub, hoop, table, wicket, vane, sash, floor,

Work-box, chest, stringed instrument, boat, frame, and what-not.

Capitols of States, and Capitol of the nation of States.

Long stately rows in avenues, hospitals for orphans, or for the poor or sick.

Manhattan steamboats and clippers, taking the measure of all seas.

From his poem, "Crosssing [sic] Brooklyn Ferry," the following passage is taken. Speaking to those of a future generation, who will cross the East River, he says: 
Just as you feel when you look on the river, and sky, so I felt;

Just as any of you is a living crowd, I was one of a crowd;

Just as you are refreshed by the gladness of the river and the bright glow, I was refreshed;

Just as you stand and lean on the rail, yet hurry with the swift current, I stood, yet was hurried;

Just as you look on the numberless masts of ships and the thick-stemmed pipes of steamboats, I looked.

I, too, many and many a time crossed the river-the sun half an hour high; I watched-

I watched the Twelfth month seagulls-I saw them high in the air, floating with motionless wings oscillating their bodies;

I saw how the glistening yellow lit up parts of their bodies and left the rest in strong shadow;

I saw the slow wheeling circles, and the gradual edging towards the South;

I, too, saw the reflection of the summer sky in the water-

Had my eyes dazzled by the shimmering track of beams-

Look'd at the five centrifugal spokes of light round the shape of my head in the sunlit waters,

Look'd on the haze of the hills southward and southwestward;

Look'd on the vapor as it flew, in places tinged with violet;

Look'd toward the Lower Bay to notice the arriving ships;

Saw their approach, saw aboard those that were near me;

Saw the white sails of schooners and sloops, saw the ships at anchor.

The sailors at work in the rigging or out astride the spars.

The round masts, the swinging motion of the hulls, the slender serpentine pennants;

The large and small steamers in motion, the pilots in their pilot houses;

The white wake left by the passage, the quick, tremendous whirl of the wheels;

The flags of all nations, the falling of them at sunset.

The scallop edged waves in the twilight, the ladled cups, the frolicsome cysts and glistening,

The stretch afar growing dimmer and dimmer, the gray walls of the granite storehouse by the docks.

On the river the shadowy group, the big steam tug closely flanked on each side by the barges, the hay boat, the belated lighter.

On the neighboring shore, the fires from the foundry chimneys burning high and glaringly into the night,

Casting their flicker of black, contrasted with wild red and yellow lights over the tops of houses and down into the clefts of the street.

If this be not poetry it is at least an accurate painting.

March 27, 1871, Brooklyn Daily Union, evening edition

- The World presumes that Walter Whitman, whose death was announced by the telegraph yesterday morning, "is the "famous Walt Whitman, whose name and "works," etc.; and thereupon goes into a two-column obituary, to show at once its enterprise and its knowledge of affairs. Now, the dead man may be the poet-possibly it is he; in which case we will all join the World in 
lamenting the event; but would it not have been quite as well to wait until the news of his death is confirmed before printing the cut and dried obituary which has probably been seasoning in the World's office for months past? If he should prove to be indeed dead, we could wait quietly for twenty-four hours for the publication of the obituary. If he should prove to be still alive, it will be painful for him to observe the extreme platitudes in which the World proposes to embalm his memory whenever he shall really die. Those who know the sensitiveness of the poet's soul will know how painful this experience must prove to him if he be alive and to read the World.

March 27, 1871, New York Evening Express

WALT.WHITMAN KILLED.

CROTON, N.Y., MARCH 25.-Walter Whitman was killed on the railroad, this morning, by the New York express train, bound north.

March 27, 1871, Philadelphia Evening Bulletin

\section{OBITUARY. \\ Walt Whitman.}

The World says: Our telegrams yesterday morning announced the death of Walter Whitman, crushed to death by a railroad train at Croton, N.Y. We presume that this is the famous Walt Whitman whose name and works have become household works [words] amongst us. In a scene of busy life on the high road of commerce such as he loved to frequent the most American bard of America has met his fate. His end came early to this strong man, so full of life and scarcely more than half a century old, yet little cared he of its anticipation or delay, for he held death and life of equal account if his now quaint verses have not belied him:

"Has any one supposed it lucky to be born?

I hasten to inform him or her it is just as lucky to die, and I know it."

March 28, 1871, Troy Press

WALT WHITMAN.

Walt Whitman the demoralized Ossian of America is dead. Mr. Emerson's "new sunbeam" glimmers no longer. He was run over by a railroad train at Croton in this State, on Sunday morning [telegraphs reported Saturday morning]. He was fifty-two years old,- - old enough to know better than to write the beastly stuff which some of his so-called poems contain. He was crazy to an eminent degree and nasty beyond compare. Nevertheless there is much rude poetry in his verses, which is almost spoiled by a disgusting affectation of loaferism. He was of the "red slayer" order of poets and was sublimely unintelligible at times. This happy quality was probably that which chiefly de- 
lighted Mr. Emerson. Misery loves company. His poems will never do good to anybody and are better left unread. Like Swinburne he was erratic and erotic, only more so. He wallowed in filth and splashed it over everybody that came near him. He could hardly find a publisher for his first volume, "Leaves of Grass", and it would have been better if he had never found one. He became celebrated, or rather, notorious, just as a three-legged calf might, or as the Siamese twins did. Outside of his prurient verses he is said to have been a decent man, well liked by everybody who knew him. Mr. Lincoln, admiring his verses, appointed him to a place in the Department of the Interior. Some envious person showed Secretary Harlan some of his ribald lines and that decorous official removed him. He afterwards had a desk in the Attorney General's Department. During his residence at Washington he is said to have been very kind and attentive to sick soldiers in the hospitals, and perhaps such humane acts may offset his low verses. He was a native of this State, and his ancestors for several generations were Americans, or as he expresses it in his "barbaric yawp" (to use a favorite phrase of his own) -

My tongue, every atom of my blood formed

From this soil, this air,

Born here of parents born here, from parents

The same, and their parents the same.

Peace to his ashes, and speedy forgetfulness for his filthy lines!

-A dispatch received here this morning contradicts the statement of $\mathrm{Mr}$. Whitman's death. We are not sorry to learn that he still lives, if he will write no more or write more decently. He has not only enjoyed that rare boon of reading his own obituary, but the numerous protests against his filth, which he will also read, may possibly reform him. We hope so.

March 28, 1871, Brooklyn Daily Eagle

WHITMAN.-If the Whitman killed on the railroad at Croton, on Saturday, was Walt Whitman, thousands will regretfully miss an eccentric citizen whose sympathetic nature and practical charity went as far as anything could go toward atoning for the crimes against rhyme and reason committed by him in the name of poetry.

March 28, 1871, Brooklyn Daily Union, daily edition [Same selection from "Crossing Brooklyn Ferry" as printed in the World obituary of March 27, with some differences in punctuation.]

\section{CROSSING BROOKLYN FERRY. BY WALT.WHITMAN.}

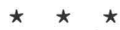

Just as you feel when you look on the river and sky, so I felt; Just as any of you is a living crowd, I was one of a crowd;
} 
Just as you are refreshed by the gladness of the river and the bright glow, I was refreshed;

Just as you stand and lean on the rail, yet hurry with the swift current, I stood, yet was hurried;

Just as you look on the numberless masts of ships and the thick-stemmed pipes of steamboats, I looked.

I, too, many and many a time crossed the river-the sun half an hour high; I watched-

I watched the Twelfth month seagulls-I saw them high in the air, floating with motionless wings oscillating their bodies;

I saw how the glistening yellow lit up parts of their bodies and left the rest in strong shadow;

I saw the slow wheeling circles, and the gradual edging towards the South;

I, too, saw the reflection of the summer sky in the water-

Had my eyes dazzled by the shimmering track of beams-

Look'd at the five centrifugal spokes of light round the shape of my head in the sunlit waters,

Look'd on the haze of the hills southward and southwestward;

Look'd on the vapor as it flew, in places tinged with violet;

Look'd toward the Lower Bay to notice the arriving ships;

Saw their approach, saw aboard those that were near me;

Saw the white sails of schooners and sloops, saw the ships at anchor.

The sailors at work in the rigging or out astride the spars.

The round masts, the swinging motion of the hulls, the slender serpentine pennants;

The large and small steamers in motion, the pilots in their pilot houses;

The white wake left by the passage, the quick, tremendous whirl of the wheels;

The flags of all nations, the falling of them at sunset.

The scallop edged waves in the twilight, the ladled cups, the frolicsome cysts and glistening,

The stretch afar growing dimmer and dimmer, the gray walls of the granite storehouse by the docks.

On the river the shadowy group, the big steam tug closely flanked on each side by the barges, the hay boat, the belated lighter.

On the neighboring shore, the fires from the foundry chimneys burning high and glaringly into the night,

Casting their flicker of black, contrasted with wild red and yellow lights, over the tops of houses and down into the clefts of the street.

\section{March 28, 1871, New York Evening Express}

WHITMAN.-Walt Whitman is still in Washington alive and well, and declares that he is neither dead nor sleeping, the column and a half obituary in a morning paper of yesterday to the contrary notwithstanding.

\section{March 28, 1871, New York Herald}

\section{A Lively Corpse.}

Walt Whitman, the poet, now in Washington, expresses his surprise that he was lately crushed to death, according to newspaper accounts, by a railroad train at Croton. 


\section{A FALSE NEWSPAPER STATEMENT.}

Walt Whitman, the poet, now in Washington, expresses his surprise that he was lately crushed to death, according to a bogus account in the New York World, by a railroad train at Croton.

March 28, 1871, Philadelphia Press

Walt Whitman.

the poet, is among those who are fortunate enough to live to read their own obituary notices. While the press of the country has been informed of his death through railroad accident, and is teeming with sketches of himself and books, he is to be seen walking the streets of this city in as good health as ever, and with fair prospect of long life yet before him.

March 28, 1871, Baltimore American and Commercial Advertiser

Mr. Walt Whitman, the poet, now in Washington, expresses surprise that he was lately crushed to death, according to newspaper accounts, by a railroad train at Croton.

March 28, 1871, Baltimore Gazette

MR. WALT WHITMAN,

the poet, now in Washington, expresses surprise that he was lately crushed to death, according to newspaper accounts, by a railroad train at Croton.

March 28, 1871, Washington Daily Morning Chronicle

THE New York World of yesterday contains a two-column obituary of Walt Whitman, the "Good Gray Poet," founded on a telegram from Croton, N.Y., stating that "Walter Whitman" had been crushed to death by a railroad train. Fortunately for the poet it was not himself, but "another man" who was killed. And here, let it be recorded, that the poet's name is not "Walter Whitman," but plain, honest, old-fashioned Walt Whitman, and nothing else. $\mathrm{He}$ is at present in excellent health; and to see his lusty form slowly swinging down the Avenue of an afternoon, one would judge him as fully capable of "sounding his barbaric yawp over the roofs of the world" as in the days when he wrote "Leaves of Grass," or studied Broadway from the top of "that omnibus." 
March 28, 1871, Washington National Daily Republican [page one]

There is a two-column obituary notice of Walt Whitman in the World. Walt ought to read it.

March 28, 1871, Washington National Daily Republican [a second item, page two]

WALT WHITMAN, whom we met yesterday on the Avenue, looking quite as much a "sublime loafer" as the New York World calls him, will be delighted to learn from the last issue of that veracious sheet that he has been "crushed to death by a railroad train at Croton, New York." Walt had no business to be absent from the Attorney General's office without leave-all young clerks be warned. Or, perhaps, he was but absent in spirit, in which case his body should don a spruce suit of mourning for the departure of such a noble and closely-related soul. The World's enterprise in first killing him and then damning him with faint praise, marks an era in journalism.

March 28, 1871, Cincinnati Daily Gazette

\section{Walt. Whitman,}

the poet, is among those who are fortunate enough to live to read their own obituary notices. While the press of the country has been informed of his death through railroad accident, and is teeming with sketches of himself and books, he is to be seen walking the streets of this city in as good health as ever, and with a fair prospect of a long life yet before him.

March 28, 1871, Chicago Tribune

NOT DEAD.

Walt Whitman, the poet, is among those who are fortunate enough to live to read their own obituary notice. While the press for the country has been informed of his death through a railroad accident, and is teeming with sketches of himself and books, he is to be seen walking the streets of this city in as good health as ever, and with the prospect of a long life before him.

March 28, 1871, St. Louis Missouri Democrat

\section{HE READS HIS OWN OBITUARY.}

Walt. Whitman, the poet, is among those who are fortunate enough to live to read his [sic] own obituary notices. While the press of the country has been informed of his death through a railroad accident, and is teeming with sketches of himself and books, he is to be seen walking the streets of this city in as good health as ever, and with a fair prospect of a long life yet before him. 
March 29, 1871, Boston Morning fournal [The following report is also found in the evening edition, March 28, 1871. It is reprinted in the June 1977 Walt Whitman Review and Walt Whitman, 1838-1939: A Reference Guide. ${ }^{8}$ This is the only newspaper report on the rumor that has been located until now.]

\section{Walt Whitman's}

Friends are enjoying an obituary notice of that true-hearted poet, who is not aware that he has been killed by a railroad accident at the North, and who is working away as usual at his desk in the Department of Justice.

\section{March 29, 1871, Washington Evening Star}

Walt Whitman is as well as could be expected for a man who has suffered from two columns of World obituary notice.

March 30, 1871, Louisville Courier-fournal [Reprints the March 27 World obituary with minor punctuation and spelling differences, and with the following heading:]

\section{WALT. WHITMAN. \\ Death of the American Swinburne-His Writings}

[From the World, March 27]

March 31, 1871, Boston Post

Walt Whitman having read a lengthy and complimentary obituary of himself, is discourteous enough to deny its truth.

\section{March 31, 1871, Cincinnati Enquirer}

WALT WHITMAN, the poet, is among those who are fortunate enough to live to read their own obituary notices. While the press of the country has been informed of his death through railroad accident, and is teeming with sketches of himself and books, he is to be seen walking the streets of Washington City in as good health as ever, and with fair prospect of long life yet before him.

April 1, 1871, Boston Daily Advertiser [Partial reprint of the March 28, 1871 Washington Daily Morning Chronicle report.]

- The New York World printed a two-column obituary of Walt Whitman, the "Good Gray Poet," founded on a despatch from Croton, N.Y., stating that "Walter Whitman" had been crushed to death by a railroad train. Fortunately for the poet it was not himself, but "another man" who was killed. 
And here (says an exchange), let it be recorded, that the poet's name is not "Walter Whitman," but plain, honest, old-fashioned Walt Whitman, and nothing else.

April 1, 1871, New York World [two sequential items]

\section{WALT WHITMAN. \\ Personal Description of the American Poet-An Interview Following an Obituary-Whitman's Personnel and Character-His Nook in the Attorney-General's Office.}

WASHINGTON, March 28.-I have often met in my walks on the avenue (Pennsylvania avenue, to speak properly), among persons noticeable for position in political or social life, a man noticeable, aside from any like considerations, for his personal grandeur. That man I never had the pleasure of meeting as an acquaintance until to-day, when, having read his obituary last evening, I felt privileged to ask an introduction through a mutual friend.

Walt Whitman (I adopt this style of naming him as that best known to the public, though the impression he has made on me would be best expressed by anything rather than an abbreviation) is a man whom once to see is never to forget. Lest this be thought a feminine enthusiasm, let me say at once that I have never read one line of his poetry save extracts I have seen in the newspapers, and that I confess to an inability to recognize anything in those extracts as what I deem true poetry. But the man I can but recognize as one of nature's noblemen. Walt Whitman, is a tall, vigorous man, portly in form, and possessing to the eye of a casual observer more flesh than muscle, yet there is reason to suppose the former does not predominate to the exclusion of the latter. $\mathrm{He}$ has what is known as a florid complexion, and it is evidently the complexion of a naturally robust man leading a healthy life. There is no tint in it indicative of coloring matter produced by other than the natural agencies of sun and air; no suspicion of artificial stimulant is suggested. His eyes are a clear though pale blue, and have a frank truthful expression-evidently the expression of a soul knowing no fear in the life which now is or that which is to come. Though I have no means of judging beyond the impression made by his appearance and a short conversation, I should say the opinion given in yesterday's WORLD was correct: Walt Whitman is certainly not a man to fear death. The hair and beard of this remarkable man meet on the sides of his face and are of uniform color-a decided gray, almost white; each is allowed to grow at will, and is worn quite long. For the rest, as regards personnel, Mr. Whitman, though deemed eccentric and by some grotesque in appearance, dresses much the same as other men, save that his clothes are larger and looser, and his shirt collar is turned back unbuttoned from his throat: a peculiarity his flowing beard serves in great measure to conceal.

Mr. Whitman is, as has been stated in THE WORLD, a clerk in the United States Attorney-General's office, and has held this position since $\mathrm{Mr}$. Harlan, now United States Senator, then Secretary of the Interior, in a fit of pious enthusiasm dismissed him from the Interior Department because of the alleged immorality of Mr. Whitman's "Leaves of Grass." His nook or corner in the Attorney-General's office is Mr. Whitman's sanctum. There he lives; in 
his lodgings he simply rests at night, or, as he says to his friends, "roosts." $\mathrm{He}$ takes his meals at a restaurant. He has a large upright desk in his office in a corner of the Treasury building, commanding one of the finest views to be obtained in this vicinity - the view, looking south from the Treasury, of the gardens belonging to the building first; of the government reservation, planted with trees; of the unfinished Washington monument; of the river beyond, and the Virginia hills farther on; and Arlington House, a white speck; and Fairfax Seminary, its cupola showing against the sky. In Fairfax Seminary some of his experiences as nurse of sick and wounded soldiers were acquired by Walt Whitman, who looks upon that portion of his life enacted during the war as the most fertile in interest and in faith implanted. Then, as he says, he saw the material of which the American people are composed thoroughly tested. Then, he says, he had the opportunity of seeing the courage, virtue, manliness, integrity, and energy of the people, as displayed in a trying emergency. The impressions gathered there are not to be shaken; and he will never be brought to believe that in any political contest the people of the United States will not be found, should they be brought to the test, equal to the occasion, however great it may be. Mr. Whitman bestows no little attention upon his surroundings, as is proved by his desk and the wall back of it still being decorated by Christmas greens - the cedar and its blue berry, the holly and its red berry, dry and scarcely beautiful now, but intended to remain, as he tells me, according to his custom, until the Christmas season comes around again. He always observes this custom, and has for several years, which observance is in itself a poem.

Attached to the inner wall of the recess formed by the doors of his upright desk are several photographs of Mr. Whitman's friends. One is of John Burroughs, a clerk in the Treasury Department, whose articles on different branches of natural history have attracted much attention in the Atlantic; another is of a beautiful young girl, with dark eyes and flowing dark hair, a perfect type of youth and health, and the beauty proceeding from the possession of both. A photograph of Alfred Tennyson also occupies a prominent place; this was presented to Mr. Whitman by a young Englishman who recently visited him, seeking him out because of enthusiasm regarding his poems. This young man, who bears the rather romantic name of Cyril Flower of Furze Down, of Surrey, England, belonged to the party of Englishmen who fell under the ban of Mrs. Yelvertson's statement - most unjustly, if the various gentlemen are believed in preference to the one lady. All Englishmen, almost without exception, who visit Washington, visit Walt Whitman.

As immorality has been charged upon his writings, so the same has been charged upon the man himself; but nothing in his appearance leads one to believe the charge of personal laxity of morals, and the evidence of his friends is altogether to the contrary. He leads a simple, harmless life, passing most of his time in his "nook" in the Attorney-General's office, having his books and pamphlets there to occupy his attention during his leisure hours. He passes as much of his time as may be in the open air, this being necessary for one of his temperament and tastes. He takes long walks by day and night. In many ways he is a "solitary," never seeking society, and encouraging none but that of his intimate friends; but he is passionately fond of music and possesses a highly cultivated taste, and is never voluntarily absent from a good concert or fine 
operatic performance. He prefers evidently classical and scientific music to ballads.

Some mistake has apparently arisen and taken firm hold on the public mind in regard to Walt Whitman's early life. He has never driven a stage, unless he may have done so as a pastime, or piloted a ferry boat. He has been connected in some manner with the press since he was seventeen years old or thereabouts. In former years he wrote stories and prose articles generally. $\mathrm{He}$ edited a leading paper in New Orleans, and at another time the Brooklyn Eagle; but wrote nothing which he himself considers worthy of remembrance until his volume of poems appeared, less than ten years ago, concerning which so many and such varied opinions exist.

MISS GRUNDY

[Revealing a desire to shift blame, the World calls attention to the Troy Press, failing to note that the Press did not exactly print an obituary (see the Press report of March 28), and that the incorrect information that it did print came from the World.]

\section{Kicking a Dead Lion.}

The Troy Press mauls poor Walt Whitman frightfully in an obituary. The editor would have been more careful with his epithets if he had known that the stalwart and muscular poet was not run over by an entire "railroad train at Croton Sunday morning":

Walt Whitman, the demoralized Ossian of America, is dead. Mr. Emerson's "new sunbeam" glimmers no longer. He was run over by a railroad train at Croton, in this State, on Sunday morning [telegraphs reported Saturday morning]. He was 52 years old-old enough to know better than to write the beastly stuff which some of his so-called poems contain.

He was crazy to an eminent degree and nasty beyond compare. Nevertheless there is much rude poetry in his verses, which is almost spoiled by a disgusting affectation of loaferism. He was of the "red slayer" order of poets and was sublimely unintelligible at times. This happy quality was probably that which chiefly delighted Mr. Emerson. Misery loves company. His poems will never do good to anybody and are better left unread. Like Swinburne, he was erratic and erotic, only more so. He wallowed in filth and splashed it over everybody that came near him. He could hardly find a publisher for his first volume, "Leaves of Grass," and he would have been better if he had never found one. He became celebrated, or rather, notorious, just as a three-legged calf might, or as the Siamese twins did.

April 1, 1871, Washington Evening Star

Under the heading, "Death of the American Swinburne," the Louisville Courier-fournal has a column and a half obituary of Walt Whitman. 
WALT. WHITMAN.-This sweet poet of the beasts is about, looking quite as well as he did before the New York World killed him off in two leaded columns, and buried him under Leaves of Grass. It would be difficult to conceive of any thing being done to Walter that would make him appear worse than he usually does. Having escaped the World he can now defy the smallpox.

\section{April 2, 1871, Chicago Tribune}

-Walt Whitman is reported to have said that, before he went to Washington, he was never the possessor of more than $\$ 6$ at any one time; and yet he has always been one of the most contented of mortals.

\section{April 2, 1871, New Orleans Daily Picayune}

\section{Walt.Whitman. \\ DEAD ONE DAY AND ALIVE THE NEXT.}

A telegraphic dispatch to New York on the 26th [25th] of March announced the death of Walter Whitman in a railway accident at Croton. Accordingly, the next issue of the World newspaper, contained a column and a half notice of the distinguished man's sudden end, which the "American Swinburne" (so called) had the not un-alloyed pleasure of perusing, inasmuch as he had a namesake, a brakesman, who was the deceased party. By the bad guess, therefore, of an editor [Manton Marble] who knew the genuine Walt., and, like persons generally, under the circumstances, must needs tell it, the country is favored with a close specification of what he is, does, was, wrote, liked, wished and lacked.

Until now Walt. Whitman has been known to the public of this section much more in the hearsay way of newspaper items than by his own work. $\mathrm{He}$ has been regarded as of the same loose and exceptional school with such as Swinburne; and without many of the merits of the Englishman who is complimented as having "made indecency popular," he's displayed as little or less regard for established modes of literature, or, indeed, for the proprieties of speech.

If our people are not so swiftly supplied with the moist-new productions of the hour as are those who live under the shadow of Northern publishing houses, it is our good fortune to escape much of the literary matter whose extreme lightness or emptiness affords too slight an impetus to project it so far.

To the candid public Whitman['s] poetry has always been unreadable: but as there are publics very much possessed with literary affectations, and as certain writers-witness Wm. Rossetti's panegyric lately noted by us-have rendered him hasty applause, which such publics regard religiously, Walt has had readers in the North and in England; and verses that ought not to have found a publisher found readers. 
One thing to be said of him is that if the present writers of poetry who hold in plain faith to the rules and methods which time, development and illustrious example have established, deprecate his literary lawlessness, so to speak, he heartily reciprocated their dislike, (if the World is correct,) and spake and wrote vigorously against what he superciliously called " - a few silly fans languidly moved by shrunken fingers."

What we might call the Whitman style, if there is a style in his verses, is a clean ignoring of measure and rhythm, generally of rhyme and, by no means seldom, sense. He is rugged in the greatest extreme, graphic, singular, unnatural, presumptuous, and, we trust, ephemeral. It is without doubt an error that he was ever an editor in New Orleans. If he was he certainly was not prominent, as the fact has escaped the memory of those who remember with accuracy the history of the news of this city for nearly forty years back. New Orleans will have to decline the honor.

April 3, 1871, New York Tribune [from "Swinburne at Home" published in the August 1871 Galaxy, reprinted in the New York World 24 July 1871]

Swinburne's admiration for Walt Whitman is excessive. He has every edition that has been printed of Walt Whitman's poems, and maintains that, while there can be no dispute that Victor Hugo is the greatest living poet, he is very much inclined to think that Walt Whitman holds the disputed second place.

\section{April 4, 1871, Washington Daily Morning Chronicle}

SWINBURNE'S admiration for Walt Whitman is excessive. He has every edition that has been printed of Walt Whitman's poems, and maintains that, while there can be no dispute that Victor Hugo is the greatest living poet, he is very much inclined to think that Walt Whitman holds the disputed second place.

April 4, 1871, Chicago Tribune [partial reprint of 28 March Washington Daily Morning Chronicle]

- The New York World printed a two-column obituary of Walt Whitman, the "Good Gray Poet," founded on a despatch from Croton, N.Y., stating that Walter Whitman had been crushed to death by a railroad train. Fortunately for the poet it was not himself, but "another man," who was killed. And here, says an exchange, let it be recorded, that the poet's name is not "Walter Whitman," but plain, honest, old-fashioned Walt Whitman, and nothing else.

April 5, 1871, Washington Daily Patriot

The poet Swinburne is an enthusiastic admirer of Walt Whitman. He has a copy of every edition of Whitman's poems that has been printed, and es- 
teems him, next in rank to Victor Hugo, as the greatest living poet. Mentioning Swinburne, personal paragraphists draw a curious picture of his half-visionary, half-erotic tendencies in public assemblies. One depicts him as carnivorously stretching his neck across the width of a room to bite the bare shoulders of a "boofer lady" present. We shall probably hear next of this talented young man as an anthropophagos.

\section{April 5, 1871, Cincinnati Enquirer}

WALT.WHITMAN.-This sweet poet of the beasts, says the Washington Sunday Capital [April 2, printed above], is about, looking quite as well as he did before the New York World killed him off in two leaded columns, and buried him under Leaves of Grass. It would be difficult to conceive of anything being done to Walter that would make him appear worse than he usually does. Having escaped the World he can now defy the small-pox.

April 5, 1871, Louisville Courier-fournal, weekly edition. [The Courierfournal reprints its notice of March 30, 1871]

WALT.WHITMAN. Death of the American Swinburne-His Writings.

April 6, 1871, New York Tribune

Tennyson's opinion of American literature is not of the highest. He refuses to recognize Walt Whitman as a poet, and is said to call Emerson "gruel electrified.”

April 6, 1871, Chicago Times

Swinburne regards Victor Hugo as the first and Walt Whitman as the second living poet.

April 7, 1871, Brooklyn Daily Eagle

Swinburne's admiration for Walt Whitman is excessive. He has every edition that has been printed of Walt's poems.

April 7, 1871, Washington Daily Morning Chronicle

TENNYSON'S opinion of American literature is not of the highest. $\mathrm{He}$ refuses to recognize Walt Whitman as a poet, and is said to call Emerson "gruel electrified." 
"RELIABLY DEAD."-The New York World after being sold to the extent of printing a two column obituary of Walt Whitman, declines to publish any more obituaries of people who are not "reliably dead." The World need not on that account hesitate to publish the obituary of the Tammany Ring,Patriot,-Merrick party of this District. It is "reliably dead."

April 9, 1871, Chicago Times

Swinburne's admiration for Walt Whitman is excessive. He has every edition that has been printed of Walt Whitman's poems, and maintains that, while there can be no dispute that Victor Hugo is the greatest living poet, he is very much inclined to think that Walt Whitman holds the disputed second place.

April 9, 1871, St. Louis Missouri Democrat

WALT.WHITMAN is reported to have said that before he went to Washington he was never the possessor of more than $\$ 6$ at any one time; and yet he has always been one of the most contented of mortals.

\section{April 19, 1871, Louisville Courier-fournal}

Tennyson's opinion of American literature is not of the highest. He refuses to recognize Walt Whitman as a poet, and is said to call Emerson "gruel electrified."

\section{University of South Carolina}

\section{NOTES}

1 I have not been able to determine who, if anyone, was killed on March 25, 1871. The New Orleans Picayune of April 2 asserts plausibly that Walter Whitman was a railroad brakeman.

2 Walt Whitman, The Correspondence, ed. Edwin Haviland Miller (New York: New York University Press, 1961), 2:123.

3 In a letter that I came across in the October 22, 1871, New York World, one George Vanderhoff wrote as follows: "SIR: I perceive by the newspapers generally that I am dead and have been buried in New York with Masonic honors. I never, as a rule, contradict anything that the newspapers say of me, but in this case it will not be considered presumptuous or egotistical to say that I am not aware of such a thing having happened to me."

4 Paine, Albert Bigelow, Mark Twain (New York: Harper, 1912), 1039.

5 See Walt Whitman, The Correspondence, 123 and 193, and Willard E. Martin's "Whitmaniana in the Boston fournal," Walt Whitman Review 23 (June 1977), 90-92. 
6 Giantvalley, Walt Whitman, 1838-1939: A Reference Guide (Boston: G. K. Hall, 1981).

7 The following lists every paper (alphabetically by city) I consulted. Generally, I searched from March 25, 1871 through April 15, 1871, for each publication:

Baltimore: American and Commercial Advertiser, Gazette, Sun.

Boston: Daily Advertiser, Evening Transcript, Herald, Morning fournal, Post.

Brooklyn: Daily Eagle, Daily Union.

Chicago: Times, Tribune.

Cincinnati: Enquirer, Daily Gazette.

Cleveland: Plain Dealer

Louisville: Commercial, Courier-fournal.

New Orleans: Bee, Commercial Bulletin, Daily Picayune, Louisianian

New York City: Albion, Evening Express, Galaxy, Herald, Evening Post, Evening Telegram, Times, Tribune, Sun, World.

Philadelphia: Evening Bulletin, Inquirer, Press.

Richmond: Enquirer.

St. Louis: Missouri Democrat, Missouri Republican.

San Francisco: Alta California, Chronicle, Evening Examiner.

Troy, NY: Press.

Washington: Sunday Capital, Daily Morning Chronicle, Georgetown Courier, Globe, Sunday Herald, National Daily Republican, New National Era, Daily Patriot, Evening Star. Wilmington, DE: fournal.

8 Martin, 90; and Giantvalley, 30. 